\title{
Xanthobacter flavus, a New Species of Nitrogen-Fixing Hydrogen Bacteria
}

\author{
K. A. MALIK aNd D. CLAUS \\ Deutsche Sammlung von Mikroorganismen, Gesellschaft für Biotechnologische Forschung mbH, D-3400 \\ Göttingen, Federal Republic of Germany
}

\begin{abstract}
Mycobacterium flavum strain 301 (= Deutsche Sammlung von Mikroorganismen 338), a hydrogen-utilizing bacterium, is capable of fixing molecular nitrogen and resembles other nitrogen-fixing hydrogen bacteria. However, it is clearly different in many characters from other strains of M. flavum (Orla-Jensen) Jensen (syn.: Microbacterium flavum Orla-Jensen). It does resemble strains of Xanthobacter Wiegel et al. with respect to cell wall composition, production of carotenoid pigments, carbon source utilization pattern, and deoxyribonucleic acid (DNA) base composition (69 mol\% guanine + cytosine). Strain 301 is here regarded as belonging to a new and distinct species, for which the name Xanthobacter flavus is proposed. Strain 301 is the type strain of this species. $X$. flavus differs from Xanthobacter autotrophicus, the only other species in this genus to date, in several respects, and the DNA-DNA hybridization between $X$. flavus and $X$. autotrophicus is only $25 \%$.
\end{abstract}

In 1961 Federov and Kalininskaya (13) isolated an aerobic, nitrogen-fixing bacterium (strain 301) from turf podzol soils and identified it according to Krasil'nikov's scheme (18) as a member of Mycobacterium flavum (Orla-Jensen) Jensen (syn.: Microbacterium flavum OrlaJensen). Subsequently, various authors $(2-4,6)$ studied the nitrogen-fixing system of this strain, which has also been included in comparative studies $(10,25)$ on nitrogen-fixing hydrogen bacteria.

Even though Mycobacterium flavum and Microbacterium flavum are objective synonyms $(7-9,17)$, there has been considerable confusion between Mycobacterium flavum and strains identified as belonging to Microbacterium flavum, of which none of Orla-Jensen's original strains are extant. For example, Biggins and Postgate (5) showed that Mycobacterium flavum 301 differs from Microbacterium flavum National Collection of Industrial Bacteria [NCIB] 8707 (= ATCC $10340=$ Deutsche Samlung von Mikroorganismen [DSM] 20296) and stated that neither strain agrees with OrlaJensen's original description of Microbacterium flavum (19).

Furthermore, Microbacterium flavum has a cell wall structure of the "arabinose-galactosemeso-diaminopimelic acid" type (22), whereas the cell wall of Mycobacterium flavum has no arabinogalactone or mycolic acid. Microbacterium flavum has a deoxyribonucleic acid (DNA) base content of 58 to $59 \mathrm{~mol} \%$ guanine plus cytosine (G+C), and Mycobacterium flavum 301 has a $\mathrm{G}+\mathrm{C}$ content of $69 \mathrm{~mol} \%$ (5).
Tsukamura (24) showed that unlike most rapidly growing mycobacteria, strain 301 has no mycobactin. Mycobacteria are usually gram positive and strongly acid fast, but strain 301 is gram variable and weakly acid fast. Erickson (12) reported that strain 301 has ubiquinone but no menaquinone, whereas most mycobacteria and other gram-positive organisms contain only menaquinone. Erickson also reported that there are important differences between the respiratory system of strain 301 and those of mycobacteria and that the electron transport system of strain 301 is unique.

Thus, there has been considerable confusion regarding the taxonomic position of strain 301 $(5,10,25)$, and it has been suggested that this strain is a member of the genus Corynebacte. rium (10). However, the taxonomy of the Cory. nebacteriaceae, especially those that are nitrogen-fixing bacteria, has been a subject of controversy itself. Biggins and Postgate (5) compared Mycobacterium flavum 301 with corynebacteria, arthrobacters, nocardiae, and mycobacteria and concluded that strain 301 should be reclassified.

Wiegel et al. (25) extensively studied the nitrogen-fixing hydrogen bacteria and transferred Corynebacterium autotrophicum Baumgarten et al. to a new genus, for which they proposed the name Xanthobacter. Howeve., no satisfactory recommendations have been made for strain 301 , whose precise taxonomic position remains unclear.

Because strain 301 grows chemolithotrophically with hydrogen (10) and is capable of fixing molecular nitrogen, a taxonomic comparison of 
this strain with Xanthobacter autotrophicus was indicated. This paper reports the results of this study.

\section{MATERIALS AND METHODS}

Bacterial strains. A culture of Mycobacterium flavum 301 (= DSM 338 = NCIB 10071) was obtained from the DSM and was characterized to confirm its authenticity. The identity of this strain was further confirmed by comparing it with a culture of Mycobacterium flavum 301 obtained from G. Zavarzin, Institute of Microbiology, USSR Academy of Sciences, Moscow. A culture of the type strain of $X$. autotrophicus, DSM 432, was also obtained from the DSM, as was a culture of strain DSM 685, which was isolated from garden soil at the DSM by K. A. Malik.

Growth media. A standard mineral medium with the following composition was used for growing the strains: $\mathrm{KH}_{2} \mathrm{PO}_{4}, 2.3 \mathrm{~g} ; \mathrm{Na}_{2} \mathrm{HPO}_{4} \cdot 2 \mathrm{H}_{2} \mathrm{O}, 2.9 \mathrm{~g} ; \mathrm{NH}_{4} \mathrm{Cl}$, $1.0 \mathrm{~g} ; \mathrm{MgSO}_{4} \cdot 7 \mathrm{H}_{2} \mathrm{O}, 0.5 \mathrm{~g} ; \mathrm{CaCl}_{2} \cdot 2 \mathrm{H}_{2} \mathrm{O}, 0.01 \mathrm{~g} ; \mathrm{Fe}\left(\mathrm{NH}_{4}\right)$ citrate, $0.05 \mathrm{~g}$; trace element solution SL- 6 of Pfennig (21), $6 \mathrm{ml}$; water, $1,000 \mathrm{ml}$.

For heterotrophic growth of the strains, this medium was supplemented with carbon sources $(0.2 \%$ sugar or $0.1 \%$ organic acid, unless otherwise stated). For chemolithotrophic growth, $0.05 \% \mathrm{NaHCO}_{3}$ was added, and the cultures were incubated under an atmosphere of $2 \% \mathrm{O}_{2}-10 \% \mathrm{CO}_{2}-28 \% \mathrm{~N}_{2}-60 \% \mathrm{H}_{2}$. For growth on nitrogen-free medium, $\mathrm{NH}_{4} \mathrm{Cl}$ was omitted, $0.2 \%$ sodium succinate was added to the mineral medium, and cultures were incubated under $2 \% \mathrm{O}_{2}$ and $98 \% \mathrm{~N}_{2}$.

Methods. Growth factor requirements of the strains were determined according to the method of Holding and Collee (16). The standard mineral medium was supplemented with the following: sodium acetate, $0.1 \%$; sodium lactate, $0.1 \%$; sodium succinate, $0.1 \%$; and glucose, $0.2 \%$. When necessary, the standard medium was supplemented with the following vitamin solution: thiamine, riboflavin, nicotinic acid, pyrdoxin$\mathrm{HCl}$, and calcium pantothenate, each at a concentration of $1 \mu \mathrm{g} / \mathrm{ml}$, and vitamin $\mathrm{B}_{12}$, biotin, and folic acid, each at $0.1 \mu \mathrm{g} / \mathrm{ml}$.

The utilization of compounds as sole sources of carbon was tested on agar plates by the method described by Stanier et al. (23).

DNA base composition and hybridization. For DNA preparations, the strains were grown on Difco nutrient broth containing $0.2 \%$ succinate. The method of Gillis et al. (15) was used for the purification of DNA and the determination of DNA base composition. DNA hybridization was determined optically by the renaturation rate method of De Ley et al. (11). The degree of binding was calculated according to the formula of De Ley et al. (11).

Immunological cross-reactions. Antisera to whole cells of $M$. flavum 301, Azotobacter vinelandii ATCC 13705 (= DSM 366), and X. autotrophicus strains DSM 431, 432, and 1393 were obtained from rabbits by conventional procedures. Crude serum was used throughout for testing antigen-antibody reactions, using the method of Ouchterlony (20).

\section{RESULTS AND DISCUSSION}

In Table 1 are presented the main diagnostic characters of Mycobacterium flavum 301 and X. autotrophicus. Both produce circular, entire, convex, and opaque colonies on nutrient agar. A comparison of the major characters shows that $M$. flavum 301 is quite similar to $X$. autotrophicus. Strain 301, like $X$. autotrophicus DSM 432, grows well chemolithotrophically in a mineral medium in the presence of $60 \% \mathrm{H}_{2}, 10 \% \mathrm{CO}_{2}, 2 \%$ $\mathrm{O}_{2}$, and $28 \% \mathrm{~N}_{2}$.

However, in contrast to $X$. autotrophicus DSM 432, strain 301 cannot be grown repeatedly on synthetic media without added growth factors. The addition of $0.01 \%$ yeast extract (which can be replaced with vitamin solution) promotes the autotrophic growth of strain 301 .

$X$. autotrophicus DSM 432 and M. flavum 301 can fix atmospheric nitrogen in nitrogen-deficient media under reduced oxygen pressure, and both give a positive reaction in the acetylene reduction test $(3,4,10,25)$. Many organic acids, e.g., acetic, citric, lactic, succinic, malic, fumaric, gluconic, glutaric, and glutamic acids, are utilized by both strains. Carbohydrate utilization is very limited with $X$. autotrophicus DSM 432 (only fructose and sucrose are utilized) in comparison to $M$. flavum 301. Methanol, ethanol, $n$ propanol, and $n$-butanol are utilized by both strains.

The cell shape of both $M$. flavum 301 and $X$. autotrophicus DSM 432 depends on the growth conditions. Large, irregularly branched cells were formed with media containing organic acids and small rods were produced with sugar-containing media. Due to copious amounts of extracellular slime, the daughter cells are normally held together after cell division, but no chains are formed. Within the cells, poly- $\beta$-hydroxybutyrate refractile bodies can be observed.

Wiegel et al. (25) reported that $M$. flavum 301 and $X$. autotrophicus DSM 432 resemble each other in that neither contains arabinogalactan, mycolic acids, or menaquinones and in that they have ubiquinones, the same fatty acid pattern, and similar carotenoid pigments (12).

According to Biggins and Postgate (5), broken suspensions of Microbacterium flavum NCIB 8707 gave no reaction on Ouchterlony (20) plates against antiserum to Mycobacterium flavum 301 , whereas a broken suspension of $M$. flavum 301 gave six precipitation lines.

Three wild-type $X$. autotrophicus strains (DSM 431, 432, and 1393) have a few antigens in common with $M$. flavum 301 but not with $A$. vinelandii DSM 366 . In the crossing of $X$. autotrophicus with $M$. flavum 301 antiserum 
TABLE 1. Comparison of the salient characters of Mycobacterium flavum 301 with those of the type strain of Xanthobacter autotrophicus

\begin{tabular}{|c|c|c|}
\hline Character & $\begin{array}{c}\text { X. autotrophicus DSM } \\
432^{\prime \prime}\end{array}$ & $\begin{array}{l}\text { M. flavum } 301 \mathrm{DSM} \\
338^{a}\end{array}$ \\
\hline $\mathrm{G}+\mathrm{C}$ content of DNA (mol \%) & $69-70$ & 69 \\
\hline Gram stain & Variable & Variable \\
\hline Motility & - & - \\
\hline Pigment & $\begin{array}{l}\text { Yellow, } \\
\text { carotenoid }\end{array}$ & $\begin{array}{l}\text { Yellow, } \\
\text { carotenoid }\end{array}$ \\
\hline Slime production & + & + \\
\hline Pleomorphism & + & + \\
\hline Storage material & PHB & PHB \\
\hline \multicolumn{3}{|l|}{ Cell wall composition } \\
\hline Mycolic acids & - & - \\
\hline Arabinogalactan & - & - \\
\hline Lipopolysaccharide & + & + \\
\hline Utilization of organic acids & + & + \\
\hline $\begin{array}{l}\text { Chemolithotrophic growth with hydro- } \\
\text { gen }\end{array}$ & + & + \\
\hline Nitrogen fixation & + & + \\
\hline
\end{tabular}

${ }^{a}$ According to Biggins and Postgate (5), Federov and Kalininskaya $(13,14)$, Erickson (12), and Wiegel et al. (25). PHB, Poly- $\beta$-hydroxybutyrate. Symbols: + , Positive; - , negative.

(Table 2), eight bands of differing intensities could be seen in the homologous cross. The specificity of the $M$. flavum 301 antiserum was confirmed by the fact that it showed no crosses with strains of $A$. vinelandii, Escherichia coli, Bacillus polymyxa, Corynebacterium equi, and Arthrobacter variabilis. These results indicated a taxonomic relationship between $X$. autotrophicus and $M$. flavum 301 .

For comparative purposes, including DNADNA homology determinations, an additional strain of $X$. autotrophicus, DSM 685, was also included. All the characters listed in Table 1 for $X$. autotrophicus are also exhibited by DSM 685 . However, in comparison to the limited number of carbohydrates utilized by other strains of $X$. autotrophicus, strain DSM 685 additionally utilizes cellobiose, glucose, ribose, rhamnose, mannitol, mannose, and trehalose. DSM 685 normally shows whitish, round, slimy, opaque colonies with an entire edge, and only in a very few cases is the colony color yellow like that of other strains of $X$. autotrophicus. High rates of ethylene production $(1,000$ to $1,200 \mathrm{nmol} / \mathrm{h}$ per $\mathrm{mg}$ of cell protein) were observed in cells which were grown in nitrogen-free media, autotrophically or with fructose. Strain DSM 685 requires no growth factors.

Strain DSM 685 shows 69\% DNA-DNA homology with the type strain of $X$. autotrophicus, DSM 432. Therefore, in view of its resemblance to the type strain of $X$. autotrophicus, strain DSM 685 is considered to be an authentic member of this species. Although the DNA base composition of $M$. flavum $301(69 \mathrm{~mol} \% \mathrm{G}+\mathrm{C})$ is almost the same as that of $X$. autotrophicus DSM 432 (69 to $70 \mathrm{~mol} \% \mathrm{G}+\mathrm{C})$, the DNAs from these strains showed a very low degree of binding $(25 \%)$.

In nutrient broth and media containing alcohols, $X$. autotrophicus DSM 432 produced relatively short rods and coccoid forms, whereas $M$. flavum strain 301 produced large rods with typical swollen ends and had a tendency to form filaments and rudimentary branched forms. This observation has also been supported by earlier reports (5).

The nitrogen-fixing system of $M$. flavum 301 is in common with that of Azotobacter species and is different from that of $X$. autotrophicus (2-4). M. flavum 301, like A. vinelandii, exhibits paramagnetic features only in the oxidized state, whereas the two ferredoxins of $X$. autotrophicus represent a new type of ferredoxin (2). After prolonged incubation, $M$. flavum 301 , in contrast to the type strain (DSM 432) of X. autotrophicus, can utilize various carbohydrates when the medium is supplemented with a vitamin solution (Table 3). Contrary to $X$. autotrophicus DSM $432, M$. flavum 301 grows very poorly with fructose and sucrose. Unlike DSM 432, $M$. flavum 301 is sensitive to oxygen. According to our own observations, normally it is aerobic but it becomes microaerophilic under autotrophic conditions. It also fixes molecular nitrogen only at low $\mathrm{pO}_{2}$ (about $\left.0.1 \mathrm{~atm}\right)(3,4)$.

In conclusion, $M$. flavum 301 appears to be a member of the genus Xanthobacter. However, 
TABLE 2. Immunological cross-reactions of Xanthobacter autotrophicus strains and Mycobacterium flavum 301 antiserum $^{a}$

\begin{tabular}{|c|c|c|c|c|c|c|c|}
\hline \multirow{2}{*}{ Antigen } & \multicolumn{7}{|c|}{$\begin{array}{l}\text { Band no. obtained with homologous strain (M. flavum 301) on Ouchterlony } \\
\text { plate }\end{array}$} \\
\hline & 2 & 3 & 4 & 5 & 6 & 7 & 8 \\
\hline X. autotrophicus DSM 432 & & & & + & & + & + \\
\hline X. autotrophicus DSM 431 & & & & & + & + & + \\
\hline$X$. autotrophicus DSM 1339 & & & & & + & + & + \\
\hline
\end{tabular}

${ }^{a}$ Data from J. R. Postgate (personal communication).

TABLE 3. Characters useful for the differentiation of the currently known species of Xanthobacter

\begin{tabular}{lcc}
\hline \multicolumn{1}{c}{ Character } & X. flavus & $\begin{array}{c}\text { X. autotro- } \\
\text { phicus }\end{array}$ \\
\hline $\begin{array}{l}\text { Requires growth fac- } \\
\text { tors }\end{array}$ & + & - \\
Sensitivity to oxygen & & \\
Nitrogen-fixing system & + & - \\
similar to that of & + & - \\
Azotobacter & & \\
Utilization of: & & \\
Acetate & $(+)$ & + \\
Propionate & - & + \\
Malonate & + & - \\
Fructose & $(+)$ & + \\
Sucrose & $(+)$ & + \\
Arabinose & $(+)$ & - \\
Glucose & + & - \\
Maltose & + & - \\
Cellobiose & $(+)$ & - \\
Ribose & + & - \\
Trehalose & $(+)$ & - \\
Xylose & $(+)$ & - \\
L-Histidine & + & - \\
L-Phenylalanine & + & - \\
\hline When cell are & &
\end{tabular}

"When cells are grown under chemolithotrophic conditions. Symbols: + , Positive; - , negative; $(+)$, poor growth.

the phenotypic differences (see Table 3 ) between $M$. flavum 301 and the type strain of $X$. autotrophicus, DSM 432, and the low DNA-DNA homology between the two strains justifies their separation into distinct species. Accordingly, the name Xanthobacter flavus sp. nov. (flavus. L.adj. flavus yellow) is here proposed for the species which includes the strain formerly known as Mycobacterium flavum 301. It should be noted that strain 301 is not the type strain of Mycobacterium flavum. In fact, strain 301 is merely a strain which was incorrectly identified as a member of $M$. flavum. Under these circumstances, it is clear that we are not proposing the transfer of the species $M$. flavum to Xanthobacter.

Xanthobacter flavus sp. nov. At present, only one strain of this species is known, i.e., the type strain. Consequently, the following serves as the description of both the species and the type strain.

Cells are rod shaped and measure 0.5 to 0.7 by 1.0 to $2.5 \mu \mathrm{m}$; irregularly branched cells occur on media containing organic acids. Typically the cells have swollen ends; there is a tendency to filament formation. Gram variable. Nonmotile. Endospores are not produced. The cell walls do not contain arabinogalactan or mycolic acids.

Agar colonies are pale yellow or creamy, opaque, slimy, circular, entire, and convex.

Chemoorganotrophic and facultatively chemolithotrophic.

Atmospheric nitrogen is fixed in nitrogen-deficient media.

Aerobic but microaerophilic under chemolithotrophic conditions and while fixing molecular nitrogen.

Requires $\mathrm{B}_{12}$, biotin, or riboflavin.

Many types of organic acids can be utilized. Many carbohydrates are also utilized, but most of these only after prolonged incubation.

Temperature for optimal growth: about $30^{\circ} \mathrm{C}$. $\mathrm{G}+\mathrm{C}$ content of the DNA: $69 \mathrm{~mol} \%$.

Other major characters are listed in Tables 1 and 3.

Type strain: strain 301 (= DSM $338=$ NCIB 10071). This strain was isolated by Federov and Kalininskaya in 1961 from turf podzol soil in the USSR and was then identified as a member of Mycobacterium flavum $(13,14)$.

\section{ACKNOWLEDGMENTS}

We are very grateful to J. R. Postgate, The University of Sussex, Falmer, Brighton, Sussex, England, who very kindly provided us with his results on serological testing. We also thank H. G. Schlegel for his interest and helpful advice and R. Müller for skilled technical assistance.

\section{REPRINT REQUESTS}

Address reprint requests to: Dr. K. A. Malik, Deutsche Sammlung von Mikroorganismen, Gesellschaft für Biotechnologische Forschung mbH, Grisebachstrasse 8, D-3400 Göttingen, Federal Republic of Germany.

\section{LITERATURE CITED}

1. Baumgarten, J., M. Reh, and H. G. Schlegel, 1974. Taxonomic studies on some Gram-positive coryneform 
hydrogen bacteria. Arch. Microbiol. 100:207-217.

2. Berndt, H., D. J. Lowe, and M. G. Yates. 1978. The nitrogen-fixing system of Corynebacterium autotrophicum. Eur. J. Biochem. 86:133-142.

3. Biggins, D. R., and J. R. Postgate. 1969. Nitrogen fixation by cultures and cell-free extracts of Mycobacterium flavum 301. J. Gen. Microbiol. 56:181-193.

4. Biggins, D. R., and J. R. Postgate. 1971. Nitrogen fixation by extracts of Mycobacterium flavum 301. Eur. J. Biochem. 19:408-415.

5. Biggins, D. R., and J. R. Postgate. 1971. Confusion in the taxonomy of a nitrogen-fixing bacterium currently classified as Mycobacterium flavum 301. J. Gen. Microbiol. 65:119-124.

6. Bothe, H., and M. G. Yates. 1976. The electron transport to nitrogenase in Mycobacterium flavum. Arch. Microbiol. 107:25-31.

7. Breed, R. S., E. G. D. Murray, and A. P. Hitchins. 1948. Bergey's manual of determinative bacteriology, 6th ed. The Williams \& Wilkins Co., Baltimore.

8. Breed, R. S., E. G. D. Murray, and N. R. Smith. 1957. Bergey's manual of determinative bacteriology, 7th ed. The Williams \& Wilkins Co., Baltimore.

9. Buchanan, R. E., and N. E. Gibbons. 1974. Bergey's manual of determinative bacteriology, 8 th ed. The Williams \& Wilkins Co., Baltimore.

10. Debondt, J. A. M., and M. W. M. Leijten. 1976. Nitrogen fixation of hydrogen-utilizing bacteria. Arch. Microbiol. 107:235-240.

11. De Ley, J., H. Cattoir, and A. Reynaerts. 1970. The quantitative measurements of DNA hybridization from renaturation rates. Eur. J. Biochem. 12:133-142.

12. Erickson, S. K. 1971. The respiratory system of the aerobic, nitrogen-fixing Gram-positive bacterium, $M y$ cobacterium flavum 301. Biochim. Biophys. Acta 245: 63-69.

13. Federov, M. V., and T. A. Kalininskaya. 1961. A new species of nitrogen-fixing Mycobacterium and its phys- iological properties. Mikrobiologiya 30:9-14.

14. Federov, M. V., and T. A. Kalininskaya. 1961. The relation of the nitrogen-fixing Mycobacterium (Mycobacterium sp. 301) to various carbon sources and to additional growth factors. Mikrobiologiya 30:833-840.

15. Gillis, M., J. De Ley, and M. De Cleene. 1970. The determination of molecular weight of bacterial genome DNA from renaturation rates. Eur. J. Biochem. 12:143153.

16. Holding, A. J., and J. G. Collee. 1971. Routine biochemical tests, p. 12. In J. R. Norris and D. W. Ribbons (ed.) Methods of microbiology, vol. 6A. Academic Press Inc. London.

17. Jensen, K. L. 1934. Studies on saprophytic mycobacteria and corynebacteria. Proc. Linn. Soc. N.S.W. 59:19.

18. Krasil'nikov, N. A. 1959. Diagnostik der Bakterien und Actinomyceten. VEB Gustav Fischer Verlag, Jena.

19. Orla-Jensen, S. 1919. The lactic acid bacteria. Høst, Copenhagen.

20. Ouchterlony, O. 1949. Antigen-antibody reactions in gels. Acta Pathol. Microbiol. Scand. 26:507-515.

21. Pfennig, N. 1974. Rhodopseudomonas globiformis, sp.n., a new species of Rhodospirillaceae. Arch. Microbiol. 100:197-206.

22. Robinson, K. 1966. Some observations on the taxonomy of the genus Microbacterium. I. Cultural and physiological reactions and heat resistance. J. Appl. Bacteriol. 29:607-615.

23. Stanier, R. Y., N. J. Palleroni, and M. Doudoroff. 1966. The aerobic pseudomonads: a taxonomic study. J. Bacteriol. 87:293-302.

24. Tsukamura, M. 1966. Adansonian classification of mycobacteria. J. Gen. Microbiol. 45:253-273.

25. Wiegel, J., D. Wilke, J. Baumgarten, R. Opitz, and H. G. Schlegel. 1978. Transfer of the nitrogen-fixing hydrogen bacteria Corynebacterium autotrophicum Baumgarten et al. to Xanthobacter gen. nov. Int. J. Syst. Bacteriol. 28:573-581. 